Open Access

\title{
Panama canal expansion, U.S. trade diversion from west coast seaports and urban innovation
}

\author{
ChangKeun Park ${ }^{1}$ and JiYoung Park ${ }^{2^{*}}$
}

\author{
* Correspondence: \\ jp292@buffalo.edu \\ ${ }^{2}$ Department of Urban and Regional \\ Planning, University at Buffalo, 05L \\ Hayes Annex C, Buffalo, NY \\ 14214-3087, USA \\ Full list of author information is \\ available at the end of the article
}

\begin{abstract}
Adapting to the rapid process of globalization requires nodes of international trade and global financial operations conveyed in the world urban system. Urban and metropolitan areas need to strategically approach to incorporating the city economic activities to enlarge the scope and complexity of the city service and commodity. Because strong urban agglomerations usually lead to technological innovation, investigating the relation between the expansion of Panama Canal and its state and regional economic impacts that will be potentially affected within the U.S. can provides various policy insights in urban growth and technical innovations for the local areas. This study estimated reduced impacts of transportation and warehousing activities for foreign imports and exports for the west coast seaports of California, Oregon, and Washington as well as the concurrent impacts in other states stemming from the trade diversion in their direction, which will affect urban growth and innovation. We applied both the supply- and demand-side National Interstate Economic Models. We assumed that foreign imports and exports that currently arrive and leave the west coast customs district ports and are now transported to other U.S. Southern and East Coast states by truck and rail modes would be directly shipped to these other states via the deepened and expanded Panama Canal. The total negative impacts of transportation and warehousing values lost in the three west coast states from foreign import diversion were estimated to be \$5795 million; for foreign exports, \$1630 million. However, total positive gains due to the shift of transportation modes and new warehousing activities for foreign imports in the other states were estimated at $\$ 6304$ million, while the gains were $\$ 9218$ million for the case of foreign exports. The net impacts resulting from port modernization investment and shipping route changes will be an economic engine to affect U.S. states.
\end{abstract}

Keywords: Panama canal expansion, Economic model, NIEMO, West coast seaports, Economic impacts

\section{Introduction}

The Panama Canal Authority in 2006 decided to invest more than $\$ 5$ billion to expand the Canal to increase container shipment capacity. The expanded Canal will accommodate larger vessels that cannot now traverse the facility. Along with capacity expansion, the project is expected to have significant impacts on U.S. water and ground carriers, including transportation systems relating to cargo distribution, port development, U.S.

(c) 2016 The Author(s). Open Access This article is distributed under the terms of the Creative Commons Attribution 4.0 International License (http://creativecommons.org/licenses/by/4.0/), which permits unrestricted use, distribution, and reproduction in any medium, provided you give appropriate credit to the original author(s) and the source, provide a link to the Creative Commons license, and indicate if changes were made. 
supply chains, and logistics. According to CanagaRetna (2013) and Knight (2008), the expansion will induce an even greater flow of container trade between Asian countries and the U.S., and hence, trade volumes arriving at Gulf and Atlantic Coast ports are also expected to increase as shipping cargo shifts from the congestion experienced in West Coast ports.

Urban economic growth in urban cities is mainly geared by urban innovation process. Urban innovation process is reached by deepening by capital and increasing in human resource through technologically innovative progress and agglomeration economies in urban areas. Urban cities are rapidly experiencing globalization process. Adapting to the process requires nodes of international trade and global financial operations conveyed in the world urban system. Urban cities need to strategically approach to incorporating the city economic activities to enlarge the scope and complexity of the city's service and commodity activities. This comprises strong urban agglomerations that usually lead to technological innovation, increasing per-capita income of residents and laborers in urban cities.

Investigating the relationship between the expansion of Panama Canal and its state and regional economic impacts that will be potentially affected within the U.S. can provides various policy insights in urban growth and technical innovations in the U.S. For example, while West Coast cities may have inverse experiences, increase in international trade in East Coast cities may experience technological innovations through the new modernization investment process in bays and port facilities, which in turn lead to urban growth. Changes in international trade patterns and activities of transportation industry draw various discussions in technological innovations. Through this study, stakeholders of the canal expansion and policy makers will get basic grounds of their decision making process of investment adapted to globalization and new technical innovation process needed to expand their port capacities.

However, estimating the U.S. economic effects of the Panama Canal expansion is complicated. It should consider various domestic and foreign policies as well as global economic situations. To understand the overall impacts is to connect an economic impact model with trade pattern change stemming from the canal expansion because the economic impact can be understood as a main capital asset and easily transferred to number of jobs. Therefore, urban innovation that is understood as urban growth resulted from technical innovation in urban areas can be measured via an economic impact analysis. An issue is to be answered is how to measure the local impact due to the lack of a geographically disaggregate economic model in the U.S.

The simplest way to approach the problem is to apply a spatially disaggregate inputoutput (IO) model. The National Interstate Economic Model (NIEMO), which models all interstate trade relations among the U.S. states, is useful. As Park (2008) suggested, imports and exports require a separate IO model application and NIEMO's capability to estimate demand- and supply-side impacts is important to this type of study. Larger ships passing through the Canal will redirect sizable water-borne trade among U.S. ports, affecting the use of the other freight modes.

In this paper, we provide negative and positive estimates using secondary imports and exports data available from WISERTrade (www.wisertrade.org). First, we measured reduced seaborne imports and exports to the West Coast Customs Districts (WCCD: Los Angeles Customs District, San Francisco Customs District, Columbia-Snake Customs 
District, and Seattle Customs District). The reduced port activities would occur in California, Oregon, and Washington, the states that receive foreign imports and send foreign exports. However, concurrent positive effects in the other states should be considered from increased imports and exports.

\section{Studies on the panama canal expansion}

In the emerging global economy, the primary driver of urban economic development has shifted from mass-production industries and low-skill service jobs to a sophisticated technology- and knowledge-based system of production and services. Therefore, international trade and investment will be key factors of urban and regional growth and crucial sources of local jobs and wealth. For improving or even maintaining their economic position, cities must provide the labor force, services, and infrastructure that allow locally based domestic and foreign-owned firms to participate more successfully in the international marketplace (Rondinelli et al., 1998).

Through its emergence as an important transshipment center for goods to/from Latin America and the Caribbean, Miami's economy can be revitalized. Over $50 \%$ of U.S. trade with Caribbean countries and nearly 40 \% of U.S. trade with Latin America transported through Miami (Jones, 1996). Los Angeles County and its surrounding areas attracted more than 140,000 jobs through the growth in business services, tourism, entertainment, and wholesaling largely attributed to international trade in 1995 (Kotkin, 1996). Also, Rondinelli et al. (1998) revealed that Detroit's economic recovery is being driven largely by the sharp increases in international sales of automobile industry, automotive suppliers, and other high-technology, high-value-added industries located in and around the city. Moreover, Urban (2007) identified the welfare of trade openness gains through a model that explains income divergence in a poverty trap regime, income convergence in a neoclassical regime, and a testable condition under which a country is depending on the degree of integration in product markets.

Recently, some research reports and papers have discussed plausible implications of the Panama Canal expansion. Rodrigue (2010) outlined the present Panama Canal functions and provided arguments for the expansion of the Canal. He categorized three main factors that may contribute to the expansion: macroeconomic factors (associated with changes in aggregate demand and the production structure), operational factors (related to freight distribution along the maritime shipping), and competitive factors (affecting other transport chains). However, predicting the economic impacts of the canal expansion is also a multidimensional function. As Knight (2008) summarized, it is necessary to consider the timing and location of the impacts on freight distribution to avoid possibly inconsistent economic assumptions associated with the Panama Canal expansion.

The timing and location complexity involves investment strategies planned in each port. A number of ports on the Atlantic and Gulf Coasts have initiated work on port expansion and modernization effort so as to ensure taking a greater proportion of global trade to their ports, responding to the Panama Canal expansion (CanagaRetna, 2013). More specifically, Boske and Harrison (2013) analyzed major aspects of trade between the U.S. and Asian countries as well as U.S.-Latin American trade, suggesting opportunities and challenges from canal expansion faced by Texas ports from 
competition of international trade. However, it is still unknown which states will be losers or winners in terms of economic impacts.

Another important research topic associated with canal expansion is to estimate environmental impacts. Using imports and exports projection data available from the Freight Analysis Framework (FAF) 3 database of the Federal Highway Administration, Bittner et al. (2012) estimated the potential impacts of canal expansion on greenhouse gas (GHG) emissions from trade between the U.S. and East and Southeast Asian countries. Focusing on GHG emissions changes and linking the size of ships and waterborne route distances, Corbett et al. (2012) probed more detailed the impacts: substitution to larger ships traversing the expanded Canal can reduce $\mathrm{CO}_{2}$ emissions; however, longer water-borne route distances offset modal efficiencies in $\mathrm{CO}_{2}$ emissions. It is not clear that diversion from the west coast ports to the south and east coast ports would reduce $\mathrm{CO}_{2}$ emissions.

While all the studies reported recently, including environmental impact studies, did not address economic impacts due to many uncertainties involved, they do offer much useful information. For example, which states would expect a potential increase in water-bone shipping by the Panama Canal expansion? How can an IO model involve route-distance data by mode when addressing the economic impacts for various states which have different location from each port and time frame to be delivered? The next section explains how we modeled various complex questions which had not previously been addressed in economic impact analyses in the U.S.

\section{Model and data}

We applied the supply- and demand-side NIEMOs for the analysis and estimated the state-by-state and industry-by-industry economic impacts on the Panama Canal expansion for imports and exports. As input data for the application of the NIEMO models to trade diversion effects for the WCCD area, we collected and modified foreign imports and exports data available from WISERtrade, which is collected from the U.S. Census Bureau's Foreign Trade Division. We selected 15 Pacific Rim countries that traded with the WCCD ports. These include China, Japan, Republic of Korea, Hong Kong, Singapore, Australia, Taiwan, Malaysia, Philippines, Indonesia, New Zealand, Macao, Papua New Guinea, Brunei, and Thailand. Three-year average values of total imports and exports between 2010 and 2012 were calculated to mute the effects of outlier values. The second column in Table 1 shows the resulting imports and exports data by customs districts of the West Coast states.

We also derived transportation (each truck and rail mode) and warehousing margins for total foreign imports and exports, respectively. For this purpose, we used a use table from the National Input-output Accounts available from the Bureau of Economic Analysis (www.bea.gov). Multiplying these margins by the total imports and exports of each Customs District, we calculated the transportation and warehousing related activity values for foreign imports (upper table) and exports (lower table). The results are displayed in the third and fourth columns of Table 1 by each WCCD.

We allocated transportation and warehousing values of freight destined for other states. Based on the studies of Rodrigue (2010) and Knight (2008), we chose 12 states with seaports potentially impacted by the Panama Canal expansion. They are Alabama, Delaware, Florida, Georgia, Maryland, Massachusetts, New Jersey, New York, 
Table 1 Selected foreign water-borne trade data to West Coast Customs Districts

\begin{tabular}{lllll}
\hline Customs District & Total imports & \multicolumn{2}{l}{ Transportation cost } & Warehousing cost \\
& & Rail & Truck & \\
Los Angeles & $169,518.14$ & $4,059.60$ & $10,954.29$ & $4,109.48$ \\
San Francisco & $23,733.60$ & 568.37 & $1,533.67$ & 575.35 \\
Columbia-Snake & $9,452.28$ & 226.36 & 610.81 & 229.14 \\
Seattle & $28,831.68$ & 690.46 & $1,863.11$ & 698.94 \\
Total & $231,535.70$ & $5,544.79$ & $14,961.88$ & $5,612.91$ \\
Customs District & Total exports & Transportation cost & Warehousing cost \\
& & Rail & Truck & \\
Los Angeles & $65,359.67$ & $1,565.23$ & 4223.55 & $1,584.46$ \\
San Francisco & $13,461.79$ & 322.38 & 869.90 & 326.34 \\
Columbia-Snake & $10,335.69$ & 247.52 & 667.89 & 250.56 \\
Seattle & $17,784.75$ & 425.91 & 1149.25 & 431.14 \\
Total & $106,941.91$ & $2,561.03$ & $6,910.61$ & $2,592.50$ \\
\hline
\end{tabular}

Note: Imports and exports values are averaged from 2010 through 2012

Units: millions of dollars

Pennsylvania, South Carolina, Texas, and Virginia. To distribute transportation and warehousing amounts to these states, we applied the modal proportions of the Freight Analysis Framework version $3\left(\mathrm{FAF}^{3}\right)$. More specifically, we used the Origin-destination State Database for 2007 available from the U.S. Department of Transportation, Federal Highway Administration. Even though the FAF data have some limitation, the data source is still useful because it provides substantial freight movement data among U.S. states and major metropolitan areas by every major freight mode used for transport (Park et al., 2011).

Equation 1 explains the distribution process. From the $2007 \mathrm{FAF}^{3}$ database, we calculated the portion of foreign imports and exports that are distributed to the selected destination states from the WCCD ports via both truck and rail modes.

$$
\text { P_IMP }_{\mathrm{i}}^{\mathrm{j}}=\frac{\text { IA_TR }_{\mathrm{i}}^{\mathrm{j}}}{\mathrm{TI}_{\mathrm{i}}}, \quad \text { P_EXP } \mathrm{i}_{\mathrm{i}}^{\mathrm{j}}=\frac{\text { EA_TR }_{\mathrm{i}}^{\mathrm{j}}}{\mathrm{TE}_{\mathrm{i}}}
$$

where

P_IMP $=$ the portion of foreign imports,

P_EXP $=$ the portion of foreign exports,

$\mathrm{TI}=$ total imports,

$\mathrm{TE}=$ total exports,

IA_TR = amount of foreign imports distributed by truck and rail modes,

EA_TR $=$ amount of foreign exports distributed by truck and rail modes,

$\mathrm{i}$ = each origin state of the WCCD ports, and

$\mathbf{j}=$ each destination states.

Along with the portions allocated to each state and the transportation and warehousing costs of each WCCD suggested in Table 1, we estimated transportation and warehousing activities due to foreign imports and exports distributed to each state by truck and rail modes. Equations 2 and 3 are the bases for these estimated transportation and warehousing activity values; the estimated results are presented in Tables 2 and 3. 
Table 2 Decreased transportation and warehousing activity values of foreign imports due to diversion from each West Coast Customs District state to various states

\begin{tabular}{|c|c|c|c|c|c|c|c|c|}
\hline \multirow[t]{2}{*}{ States } & \multicolumn{2}{|c|}{ Los Angeles } & \multicolumn{2}{|c|}{ San Francisco } & \multicolumn{2}{|c|}{ Columbia-Snake } & \multicolumn{2}{|l|}{ Seattle } \\
\hline & TP value & $\overline{W H}$ value & TP value & $\overline{W H}$ value & TP value & $\overline{W H}$ value & TP value & $\overline{\mathrm{WH} \text { value }}$ \\
\hline$\overline{\mathrm{AL}}$ & 85.34 & 23.36 & 0.73 & 0.20 & 0.01 & 0.00 & 2.05 & 0.56 \\
\hline $\mathrm{DE}$ & 2.05 & 0.56 & 0.13 & 0.04 & 0.00 & 0.00 & 0.84 & 0.23 \\
\hline $\mathrm{FL}$ & 106.83 & 29.24 & 4.57 & 1.25 & 0.23 & 0.06 & 1.92 & 0.53 \\
\hline GA & 193.28 & 52.90 & 5.82 & 1.59 & 0.41 & 0.11 & 9.14 & 2.50 \\
\hline$M D$ & 27.58 & 7.55 & 1.41 & 0.39 & 0.01 & 0.00 & 6.62 & 1.81 \\
\hline MA & 40.68 & 11.13 & 6.88 & 1.88 & 0.03 & 0.01 & 3.24 & 0.89 \\
\hline NJ & 468.05 & 128.11 & 7.25 & 1.99 & 5.49 & 1.50 & 19.67 & 5.38 \\
\hline NY & 435.13 & 119.10 & 74.89 & 20.50 & 2.98 & 0.82 & 59.56 & 16.30 \\
\hline PA & 120.97 & 33.11 & 6.77 & 1.85 & 0.82 & 0.23 & 20.01 & 5.48 \\
\hline SC & 30.64 & 8.39 & 2.32 & 0.64 & 0.06 & 0.02 & 1.99 & 0.54 \\
\hline TX & 909.63 & 248.98 & 32.57 & 8.91 & 92.09 & 25.20 & 9.28 & 2.54 \\
\hline VA & 36.19 & 9.90 & 4.43 & 1.21 & 0.96 & 0.26 & 4.47 & 1.22 \\
\hline Total & $2,456.36$ & 672.33 & 147.78 & 40.45 & 103.09 & 28.22 & 138.77 & 37.98 \\
\hline
\end{tabular}

Note: TP-Transportation; WH-Warehousing Units: millions of dollars

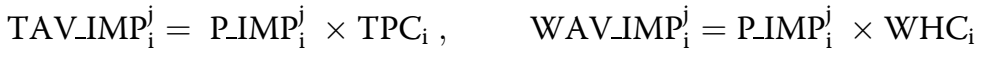

$$
\begin{aligned}
& \text { TAV_EXP }{ }_{i}^{j}=P_{-} E_{1} P_{i}^{j} \times T_{P C}, \quad \text { WAV_EXP }{ }_{i}^{j}=P_{-} E_{i} P_{i}^{j} \times W_{H}
\end{aligned}
$$

where

TAV_IMP = transportation activity value of foreign imports,

WAV_IMP = warehousing activity value of foreign imports,

TAV_EXP $=$ transportation activity value of foreign exports,

WAV_EXP = warehousing activity value of foreign exports,

TPC $=$ transportation cost of each WCCD state, and

WHC = warehousing cost of each WCCD state.

Several assumptions are needed to estimate the change of transportation activity values in destination states by modal shift. First, the transportation distance by ship from each WCCD to destination states is assumed to be identical to the geographical distance between origin and destination states. Second, the freight that would arrive at destination states will travel to the nearby areas for 100 miles only using truck mode. We approximated the highway distance miles from the core city of each WCCD to the principal cities of destination states using Google map. Finally, we used dollar values of the imports and exports data; we also used the weight data to calculate the transportation values. We assumed these freight transport costs per ton-mile: water mode is $\$ 0.0074 /$ ton-mile, truck mode $\$ 0.2619 /$ ton-mile, and rail mode $\$ 0.0228 /$ ton-mile, as Ballou (2004) suggested. The transportation activity values in destination states are shown in Tables 4 and 5.

Based on the National Interstate Economic Model (NIEMO) constructed by Park et al. (2007), we applied the demand-side and supply-side NIEMO models in this part of the study. Park $(2007 ; 2008)$ and Park et al. (2008) elaborated both demand-side and 
Table 3 Decreased transportation and warehousing activity values of foreign exports due to diversion from each West Coast Customs District state to various states

\begin{tabular}{|c|c|c|c|c|c|c|c|c|}
\hline \multirow[t]{2}{*}{ States } & \multicolumn{2}{|c|}{ Los Angeles } & \multicolumn{2}{|c|}{ San Francisco } & \multicolumn{2}{|c|}{ Columbia-Snake } & \multicolumn{2}{|l|}{ Seattle } \\
\hline & TP value & $\overline{W H}$ value & TP value & $\overline{W H}$ value & TP value & $\overline{W H}$ value & TP value & $\mathrm{WH}$ value \\
\hline$\overline{\mathrm{AL}}$ & 9.85 & 2.70 & 0.27 & 0.07 & 0.18 & 0.05 & 0.58 & 0.16 \\
\hline $\mathrm{DE}$ & 7.53 & 2.06 & 0.35 & 0.09 & 0.00 & 0.00 & 1.41 & 0.39 \\
\hline $\mathrm{FL}$ & 6.56 & 1.79 & 0.42 & 0.11 & 9.65 & 2.64 & 8.66 & 2.37 \\
\hline GA & 11.21 & 3.07 & 1.47 & 0.40 & 3.21 & 0.88 & 1.14 & 0.31 \\
\hline MD & 2.85 & 0.78 & 0.54 & 0.15 & 0.49 & 0.13 & 3.56 & 0.98 \\
\hline MA & 4.71 & 1.29 & 0.44 & 0.12 & 1.52 & 0.42 & 1.84 & 0.50 \\
\hline NJ & 22.68 & 6.21 & 1.94 & 0.53 & 8.02 & 2.20 & 4.35 & 1.19 \\
\hline NY & 44.48 & 12.17 & 4.28 & 1.17 & 112.19 & 30.71 & 20.43 & 5.59 \\
\hline PA & 19.84 & 5.43 & 1.29 & 0.35 & 27.48 & 7.52 & 4.80 & 1.31 \\
\hline SC & 2.54 & 0.69 & 0.10 & 0.03 & 0.03 & 0.01 & 1.81 & 0.50 \\
\hline TX & 378.22 & 103.52 & 16.78 & 4.59 & 3.78 & 1.03 & 2.76 & 0.76 \\
\hline VA & 24.22 & 6.63 & 1.02 & 0.28 & 0.05 & 0.01 & 5.91 & 1.62 \\
\hline Total & 534.68 & 146.35 & 28.89 & 7.91 & 166.59 & 45.60 & 57.24 & 15.67 \\
\hline
\end{tabular}

Note: TP-Transportation; WH-Warehousing Units: millions of dollars

supply-side NIEMO models, including empirical tests. Equations 4 and 5 suggest the structure of demand-side and supply-side NIEMO models in a matrix form:

$$
\mathrm{X}^{\mathrm{O}}=\left(\mathrm{I}-\mathrm{C}^{\mathrm{D}} \mathrm{N}^{\mathrm{D}}\right)^{-1} \mathrm{~F}
$$

where

$\mathrm{X}^{\mathrm{d}}=$ the total output column vector for $\mathrm{s}(=1, \ldots, 47)$ USC Sectors and $\mathrm{r}(=1, \ldots, 52)$ regions,

$C^{D}=C\left(\widehat{C}_{j}^{s}\right)^{-1}$ and $\widehat{C}_{j}^{s}$ is a sr $\times$ sr diagonal matrix of $1 \times$ sr row vector,

$\mathrm{C}_{\mathrm{j}}^{\mathrm{s}}=\sum_{\mathrm{i}} \mathrm{C}_{\mathrm{ij}}{ }^{\mathrm{s}}$ and $\mathrm{C}_{\mathrm{ij}}^{\mathrm{s}}$ is a trade flows for USC sector $\mathrm{s}$ between regions $\mathrm{i}$ and $\mathrm{j}$,

$\mathrm{N}^{\mathrm{D}}=\mathrm{Z}\left(\widehat{\mathrm{X}}^{\mathrm{I}}\right)^{-1}$ and $\widehat{\mathrm{X}}^{\mathrm{I}}$ is a sr $\times$ sr block diagonal matrix of vector $\mathrm{X}^{\mathrm{I}}$,

$\mathrm{X}^{\mathrm{I}}=$ the total input row vector,

$\mathrm{Z}=$ the block diagonal matrix of direct technical flows between industries, and

$\mathrm{F}=\mathrm{a}$ row vector of region specific final demand.

$$
\mathrm{X}^{\mathrm{I}}=\mathrm{A}\left(\mathrm{I}-\mathrm{N}^{\mathrm{S}} \mathrm{C}^{\mathrm{S}}\right)^{-1}
$$

where

$\mathrm{X}^{\mathrm{I}}=$ the total input row vector for $\mathrm{s}(=1, \ldots, 47)$ USC sectors and $\mathrm{r}(=1, \ldots, 52)$ regions, $\mathrm{A}=\mathrm{a}$ row vector of region specific value added factors,

$\mathrm{N}^{\mathrm{S}}=\left(\widehat{\mathrm{X}}^{\mathrm{O}}\right)^{-1} \mathrm{Z}$ and $\widehat{\mathrm{X}}^{\mathrm{O}}$ is a sr $\times$ sr block diagonal matrix of vector $\mathrm{X}^{\mathrm{O}}$,

$\mathrm{X}^{\mathrm{O}}=$ the total output column vector,

$\mathrm{Z}=$ the block diagonal matrix of direct technical flows between industries, and

$C^{S}=\left(\widehat{C}_{j}^{s}\right)^{-1} C$ and $\widehat{C}_{j}^{s}$ is a sr $\times$ sr diagonal matrix of $1 \times$ sr row vector,

$C_{j}^{s}=\sum_{i} C_{i j}{ }^{s}$ and $C_{i j}^{s}$ is a trade flows for USC Sector s between regions $i$ and $j$. 
Table 4 Weight and transportation activity values of foreign imports diverted from each Customs District to various states

\begin{tabular}{|c|c|c|c|c|c|c|}
\hline \multirow[t]{2}{*}{ States } & \multicolumn{3}{|c|}{ Los Angeles } & \multicolumn{3}{|c|}{ San Francisco } \\
\hline & Distance & Weight & TP_delta & Distance & Weight & TP_delta \\
\hline $\mathrm{AL}$ & 2,200 & 152,231 & 81.25 & 2,400 & 2,119 & 0.84 \\
\hline $\mathrm{DE}$ & 2,800 & 3,663 & 2.51 & 3,000 & 378 & 0.28 \\
\hline $\mathrm{FL}$ & 2,700 & 190,575 & 125.64 & 3,000 & 13,325 & 9.82 \\
\hline GA & 2,500 & 344,791 & 203.94 & 2,800 & 16,977 & 11.65 \\
\hline MD & 2,700 & 49,196 & 31.94 & 2,900 & 4,109 & 2.89 \\
\hline MA & 3,000 & 72,568 & 50.98 & 3,200 & 20,061 & 15.81 \\
\hline NJ & 2,900 & 834,941 & 587.25 & 3,000 & 21,139 & 14.24 \\
\hline NY & 2,900 & 776,213 & 539.51 & 3,000 & 218,287 & 160.89 \\
\hline PA & 2,900 & 215,800 & 152.37 & 3,000 & 19,746 & 14.52 \\
\hline SC & 2,600 & 54,659 & 34.74 & 2,800 & 6,767 & 4.64 \\
\hline TX & 1,600 & $1,622,673$ & 586.49 & 1,900 & 94,917 & 42.91 \\
\hline VA & 2,800 & 64,552 & 43.23 & 3,000 & 12,898 & 6.73 \\
\hline Average & 2,633 & 312,990 & 203.32 & 2,833 & 30,766 & 23.77 \\
\hline Total & 31,600 & $4,381,862$ & $2,439.84$ & 34,000 & 430,722 & 285.22 \\
\hline Unit & mile & ton & \$ million & Mile & ton & \$ million \\
\hline \multirow[t]{2}{*}{ States } & \multicolumn{3}{|c|}{ Columbia-Snake } & \multicolumn{3}{|l|}{ Seattle } \\
\hline & Distance & Weight & TP_delta & Distance & Weight & TP_delta \\
\hline $\mathrm{AL}$ & 2,600 & 35 & 0.022 & 2,700 & 3,911 & 1.66 \\
\hline $\mathrm{DE}$ & 2,900 & 4 & 0.003 & 2,900 & 1,602 & 1.14 \\
\hline $\mathrm{FL}$ & 3,300 & 833 & 0.678 & 3,400 & 3,671 & 3.08 \\
\hline GA & 2,900 & 1,458 & 1.038 & 3,000 & 17,441 & 12.86 \\
\hline MD & 2,800 & 49 & 0.033 & 2,800 & 12,635 & 8.67 \\
\hline MA & 3,100 & 113 & 0.071 & 3,000 & 6,174 & 4.28 \\
\hline NJ & 2,900 & 19,683 & 13.615 & 2,900 & 37,534 & 26.67 \\
\hline NY & 2,900 & 10,676 & 7.541 & 2,900 & 113,663 & 80.78 \\
\hline PA & 2,900 & 2,949 & 2.085 & 2,900 & 38,184 & 27.05 \\
\hline SC & 2,900 & 217 & 0.154 & 3,000 & 3,796 & 2.80 \\
\hline TX & 2,300 & 330,151 & 183.960 & 2,300 & 17,702 & 9.34 \\
\hline VA & 3,000 & 3,446 & 2.358 & 3,000 & 8,526 & 6.29 \\
\hline Average & 2,875 & 26,401 & 17.630 & 2,900 & 18,917 & 15.38 \\
\hline Total & 34,500 & 369,614 & 211.559 & 34,800 & 264,840 & 184.61 \\
\hline Unit & mile & ton & \$ million & Mile & ton & \$ million \\
\hline
\end{tabular}

Note: TP_delta = Baseline transportation activity values (via truck and rail modes) - Alternative transportation activity values (via water and truck modes)

The USC Sector definitions are found in Table 6. It comprises of 29 commodity and 18 service sectors, resulting in total 47 sectors. These sectors are transferable to other U.S. economic sector systems such as The North American Industry Classification System, the Standard Industrial Classification, the Standard Classification Transportable Goods, and so on. Many studies have used this USC Sector system since 2006 (see some recent examples in Richardson et al., 2014; Cho et al., 2015; Park and Richardson, 2014). 
Table $\mathbf{5}$ Weight and transportation activity values of foreign exports diverted from each Customs District to various states

\begin{tabular}{|c|c|c|c|c|c|c|}
\hline \multirow[t]{2}{*}{ States } & \multicolumn{3}{|c|}{ Los Angeles } & \multicolumn{3}{|c|}{ San Francisco } \\
\hline & Distance & Weight & TP_delta & Distance & Weight & TP_delta \\
\hline $\mathrm{AL}$ & 2,200 & 67,512 & 24.18 & 2,400 & 2,658 & 1.32 \\
\hline $\mathrm{DE}$ & 2,800 & 51,589 & 35.41 & 3,000 & 3,444 & 0.87 \\
\hline $\mathrm{FL}$ & 2,700 & 44,935 & 25.40 & 3,000 & 4,160 & 3.07 \\
\hline GA & 2,500 & 76,848 & 43.78 & 2,800 & 14,644 & 8.97 \\
\hline MD & 2,700 & 19,554 & 12.42 & 2,900 & 5,349 & 3.81 \\
\hline MA & 3,000 & 32,247 & 23.78 & 3,200 & 4,374 & 3.45 \\
\hline NJ & 2,900 & 155,447 & 96.57 & 3,000 & 19,296 & 13.96 \\
\hline NY & 2,900 & 304,856 & 216.81 & 3,000 & 42,669 & 31.46 \\
\hline PA & 2,900 & 136,006 & 86.28 & 3,000 & 12,888 & 5.73 \\
\hline SC & 2,600 & 17,385 & 9.92 & 2,800 & 1,002 & 0.55 \\
\hline TX & 1,600 & $2,592,157$ & 819.15 & 1,900 & 167,152 & 53.81 \\
\hline VA & 2,800 & 165,979 & 113.93 & 3,000 & 10,154 & 7.49 \\
\hline Average & 2,633 & 305,376 & 125.64 & 2,833 & 23,982 & 11.21 \\
\hline Total & 31,600 & $3,664,514$ & $1,507.63$ & 34,000 & 287,790 & 134.49 \\
\hline Unit & mile & ton & \$ million & Mile & ton & \$ million \\
\hline \multirow[t]{2}{*}{ States } & \multicolumn{3}{|c|}{ Columbia-Snake } & \multicolumn{3}{|l|}{ Seattle } \\
\hline & Distance & Weight & TP_delta & Distance & Weight & TP_delta \\
\hline $\mathrm{AL}$ & 2,600 & 5,516 & 3.50 & 2,700 & 8,767 & 5.79 \\
\hline $\mathrm{DE}$ & 2,900 & 3 & 0.00 & 2,900 & 21,422 & 15.25 \\
\hline $\mathrm{FL}$ & 3,300 & 298,973 & 243.26 & 3,400 & 131,776 & 110.57 \\
\hline GA & 2,900 & 99,489 & 70.82 & 3,000 & 17,388 & 12.82 \\
\hline MD & 2,800 & 15,205 & 10.44 & 2,800 & 54,214 & 37.21 \\
\hline MA & 3,100 & 47,198 & 36.00 & 3,000 & 28,017 & 20.64 \\
\hline NJ & 2,900 & 248,577 & 101.87 & 2,900 & 66,140 & 45.85 \\
\hline NY & 2,900 & $3,477,017$ & $2,475.15$ & 2,900 & 310,883 & 221.28 \\
\hline PA & 2,900 & 851,617 & 605.58 & 2,900 & 73,051 & 50.87 \\
\hline SC & 2,900 & 884 & 0.63 & 3,000 & 27,597 & 20.34 \\
\hline TX & 2,300 & 117,059 & 4.96 & 2,300 & 41,997 & 18.30 \\
\hline VA & 3,000 & 1,568 & 1.16 & 3,000 & 89,962 & 66.33 \\
\hline Average & 2,875 & 430,259 & 296.11 & 2,900 & 72,601 & 52.11 \\
\hline Total & 34,500 & $5,163,105$ & $3,553.37$ & 34,800 & 871,215 & 625.26 \\
\hline Unit & mile & ton & \$ million & Mile & ton & $\$$ million \\
\hline
\end{tabular}

Note: TP_delta = Baseline transportation activity values (via truck and rail modes) - Alternative transportation activity values (via water and truck modes)

\section{Results}

For an impact analysis of Panama Canal expansion, we assumed: foreign imports and exports that currently arrive and leave in the various WCCD ports to be transported to the other South and East Coast states via truck and rail modes would be directly shipped to these states through the deepened Panama Canal. Therefore, transportation and warehousing activity values of foreign imports and exports presented in Tables 2 and 3 are assumed to decrease in the West Coast states. To address new transportation and warehousing activities that occur in each state designated, we measured the 
Table 6 Definitions for USC Sector system

\begin{tabular}{|c|c|}
\hline USC sector & Description \\
\hline USC01 & Live animals and live fish \& Meat, fish, seafood, and their preparations \\
\hline USCO2 & Cereal grains \& Other agricultural products except for Animal Feed \\
\hline USCO3 & Animal feed and products of animal origin, n.e.c. \\
\hline USCO4 & Milled grain products and preparations, and bakery products \\
\hline USC05 & Other prepared foodstuffs and fats and oils \\
\hline USC06 & Alcoholic beverages \\
\hline USCO7 & Tobacco products \\
\hline USC08 & $\begin{array}{l}\text { Nonmetallic minerals (Monumental or building stone, Natural sands, } \\
\text { Gravel and crushed stone, n.e.c.) }\end{array}$ \\
\hline USC09 & Metallic ores and concentrates \\
\hline USC10 & Coal and petroleum products (Coal and Fuel oils, n.e.c.) \\
\hline USC11 & Basic chemicals \\
\hline USC12 & Pharmaceutical products \\
\hline USC13 & Fertilizers \\
\hline USC14 & Chemical products and preparations, n.e.c. \\
\hline USC15 & Plastics and rubber \\
\hline USC16 & Logs and other wood in the rough \& Wood products \\
\hline USC17 & Pulp, newsprint, paper, and paperboard \& Paper or paperboard articles \\
\hline USC18 & Printed products \\
\hline USC19 & Textiles, leather, and articles of textiles or leather \\
\hline USC20 & Nonmetallic mineral products \\
\hline USC21 & Base metal in primary or semi-finished forms and in finished basic shapes \\
\hline USC22 & Articles of base metal \\
\hline USC23 & Machinery \\
\hline USC24 & Electronic and other electrical equipment and components, and office equipment \\
\hline USC25 & Motorized and other vehicles (including parts) \\
\hline USC26 & Transportation equipment, n.e.c. \\
\hline USC27 & Precision instruments and apparatus \\
\hline USC28 & Furniture, mattresses and mattress supports, lamps, lighting fittings, and illuminated signs \\
\hline USC29 & Miscellaneous manufactured products, Scrap, Mixed freight, and Commodity unknown \\
\hline USC30 & Utility \\
\hline USC31 & Construction \\
\hline USC32 & Wholesale Trade \\
\hline USC33 & Transportation \\
\hline USC34 & Postal and Warehousing \\
\hline USC35 & Retail Trade \\
\hline USC36 & Broadcasting and information services \\
\hline USC37 & Finance and Insurance \\
\hline USC38 & Real estate and rental and leasing \\
\hline USC39 & Professional, Scientific, and Technical services \\
\hline USC40 & Management of companies and enterprises \\
\hline USC41 & Administrative support and waste management \\
\hline USC42 & Education Services \\
\hline USC43 & Health Care and Social Assistances \\
\hline
\end{tabular}


Table 6 Definitions for USC Sector system (Continued)

\begin{tabular}{ll}
\hline USC44 & Arts, Entertainment, and Recreation \\
USC45 & Accommodation and Food services \\
USC46 & Public administration \\
USC47 & Other services except public administration \\
\hline
\end{tabular}

difference between baseline transportation and alternative transportation modes. This accounts for transportation activity benefits in other South and East Coast states. We also allocated the decreased warehousing activity values to other destination states as increases, assuming the warehousing margin is identical there. Note that we did not account for any other transportation mode cost changes in the short-term.

Therefore, we separately estimated the reduced impacts of transportation and warehousing activities for foreign trade in the West Coast states and the increased impacts in the other states. Both the demand- and supply-side NIEMO models were applied. Because "direct impact" refers to the initial economic impact experienced in each sector in each state, it is the change of foreign imports and exports in the states presented in Tables 2 and 3 relating to the Panama Canal expansion. "Indirect impact" indicates the economic impact arising due to inter-industry linkages; this is measured via the inverse coefficients of the NIEMO models. A Type I multiplier describes the sum of direct and indirect impacts relative to direct impact.

The summary results of the reduced impacts in the West Coast states are presented in Fig. 1. The reduced impacts of transportation and warehousing values negatively affected the national economy. We show the top three impacted states and top ten USC Sectors in Fig. 1. The upper left figure presents: the most affected state was California (\$-4926 million, $85 \%$ ); Washington (\$-296 million, $5.1 \%$ ) would be second, and Oregon (\$-212 million, $3.7 \%$ ) third for the reduction of transportation and warehousing values of foreign imports in California, Oregon, and Washington by $\$ 3$ billion, $\$ 0.1$ billion, and $\$ 0.2$ billion, respectively. In the case of foreign exports, the economic losses of California, Oregon, and Washington were estimated \$1190 million (64.1\%), \$348 million (18.7\%), and $\$ 133$ million (7.2\%), based on the direct impacts of $\$ 700$ million, $\$ 200$ million, and $\$ 70$ million, respectively.

For the impacts on the top ten USC Sectors of foreign imports, the total economic losses of USC Sectors 33 (Transportation), 34 (Postal and Warehousing), and 30 (Utility) are $\$ 3109$ (53.7 \%), \$818 (14.1\%), and \$144 (2.5\%) million, respectively. The Type I multiplier in this case was 1.599. In order for USC sectors 33, 34, and 10 (Coal and petroleum products), the losses for foreign exports are sizable as \$916 (49.3\%), \$234 (12.6\%), and $\$ 111$ (6.0\%) million, respectively. The Type I multiplier for the foreign exports case was 1.851 .

The total positive gains stemming from the shift of transportation modes and new warehousing activities for foreign imports in the other states were $\$ 6304$ million; those for foreign exports were $\$ 9218$ million. The impacts in the 12 U.S. South and East Coast states and the top ten USC sectors are presented in Fig. 2. Individual economic gains from the shift of foreign imports were greatest in Texas as $\$ 1717$ million (27.2 \%), and New York (\$1413 million, 22.4\%) and New Jersey (\$1140 million, $18.1 \%$ ) were ranked the second and third benefited among 12 states. The shift gains for foreign 


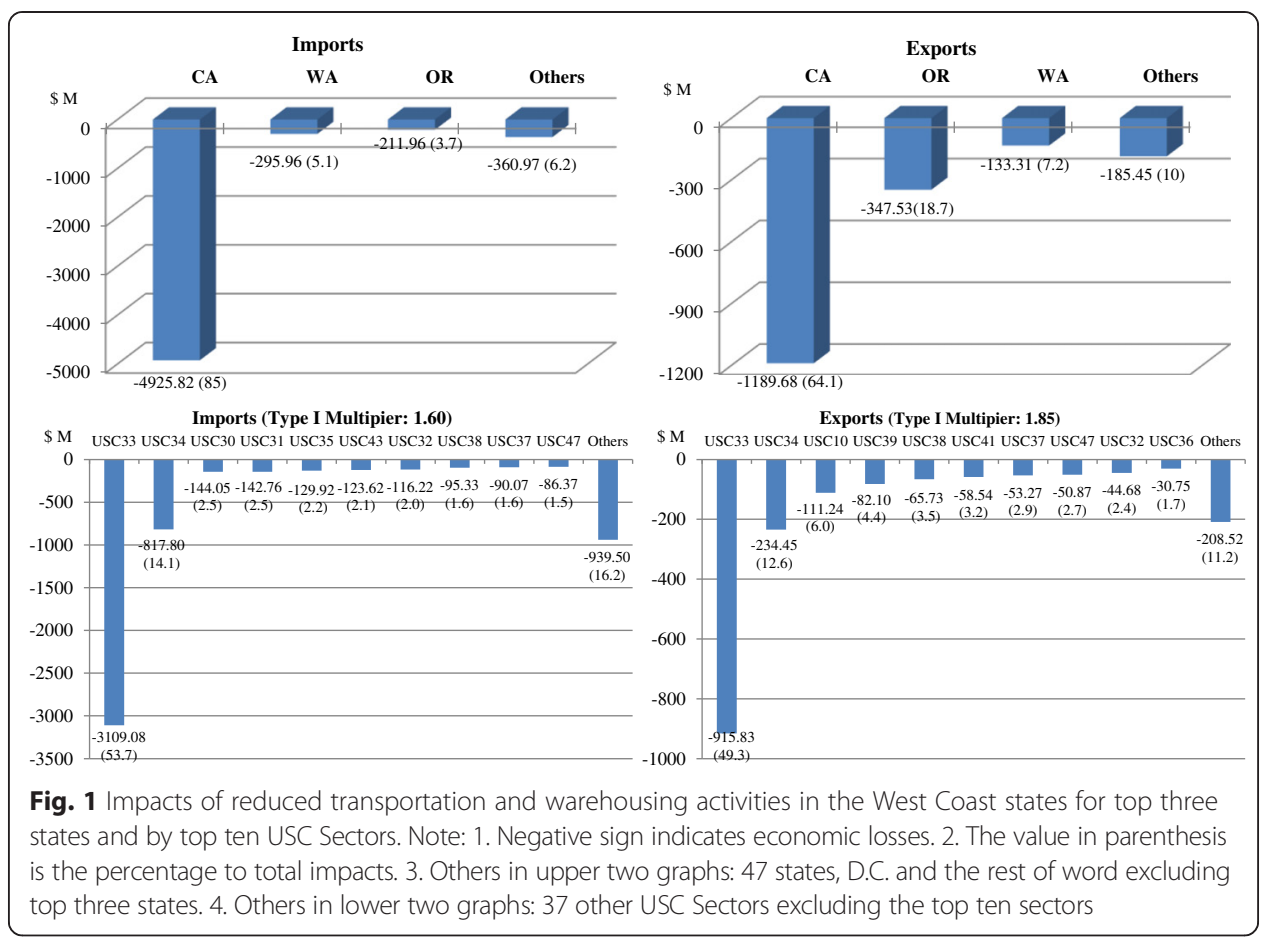

exports were considerable in New York (\$4902 million, $42.3 \%$ ), Texas (\$1909 million, $16.5 \%$ ), and Pennsylvania (\$1387 million, $12.0 \%$ ).

As transportation modes changed and warehousing activity of foreign imports to 12 states increased, the gain to USC Sector 33 (\$3467 million, $55 \%$ ) is the highest as expected, and USC Sectors 34 (\$821 million, $13 \%$ ) and 43 (Health Care and Social Assistances, $\$ 163$ million, $2.6 \%$ ) follow. The Type I multiplier in this increased activity case was 1.616. The gains for foreign exports were high in USC Sectors 33 (\$6668 million, $57.6 \%$ ), 10 (\$664 million, $5.7 \%$ ), and 39 (Professional, Scientific, and Technical services, $\$ 564$ million, $4.9 \%$ ); The Type I multiplier for the foreign exports case was 1.918 .

\section{Conclusions and discussion}

The Panama Canal expansion presents many complex issues for analysts attempting to estimate the various U.S. economic effects. There are simultaneous responses in the impacted as well as other states. Among the challenges are the problem of developing an appropriate economic model and adapting plausible scenarios to the economic model developed. We attempted to face these challenges and understand economic effects in the change of international trade pattern and activities of logistics industry in this paper.

Our approach was to apply NIEMO's supply- and demand-side interstate input-output models. We subtracted Pacific Rim imports and exports destined for the West Coast states which cover the ports in the Customs Districts of Los Angeles, San Francisco, Columbia-Snake, and Seattle and added (diverted) these volumes to various competing U.S. seaports. The results presented are the net multiplier effects of both phenomena. According to the total reduction of transportation and warehousing values for foreign imports in the West Coast ports by $\$ 3.3$ billion, the total negative impacts 


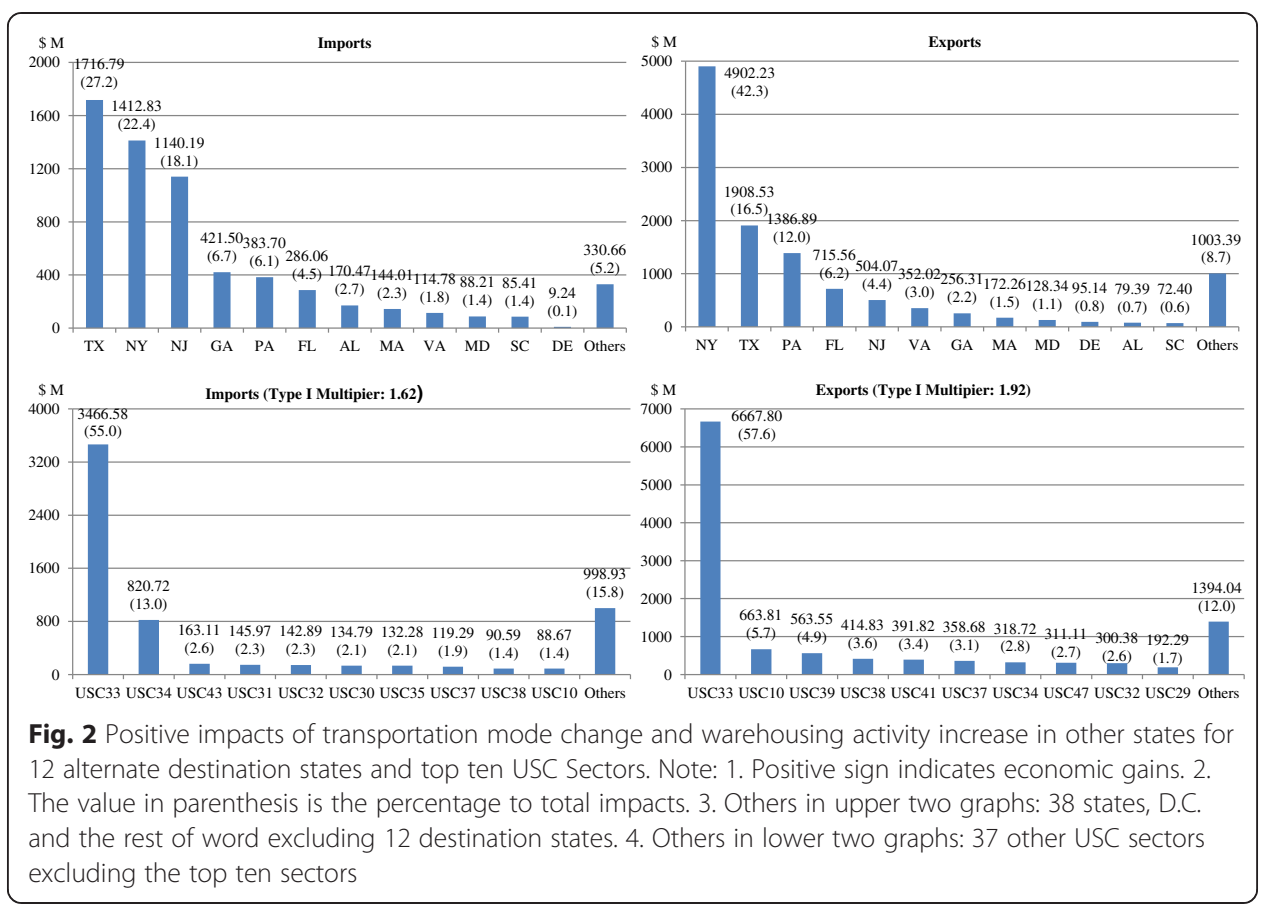

were estimated to be $\$ 5.8$ billion; those for foreign exports were $\$ 1.6$ billion. This is similar to Park's (2008) finding that foreign imports in the West Coast region account for total trade in the U.S. about four times of total foreign exports. Interestingly, total positive gains from the shift of transportation modes and new warehousing activities for foreign exports in the 12 South and East Coast states accounted for $\$ 9.2$ billion, exceeding the total gains of $\$ 6.3$ billion for foreign imports. New York and Texas would be the most benefited states in the nation. These findings will contribute to understanding how the Panama Canal expansion may affect changes in urban growth in the U.S. and future technical innovations in open economy, depending on new investment in various seaports in East Coast and its ripple impacts on other major U.S. cities.

However, it should be mentioned that the economic modeling approach adopted in this study has various limitations. First, modeling economic impacts is only useful to address short term effects. This is because an uncountable number of prices adjust in the long term and analyzing all of these economic impacts is inconceivable. Even though we applied demand-side as well as supply-side impacts for a short term as both foreign imports and exports to various U.S. ports are affected, this study did not account for how the states located in the U.S. Midwest region (Indiana, Illinois, Michigan, Ohio, Wisconsin, Iowa, Kansas, Minnesota, Missouri, Nebraska, North Dakota, and South Dakota) and the Mountain Division of West region (Arizona, Colorado, Idaho, New Mexico, Montana, Utah, Nevada, and Wyoming) would change their entry points for foreign trade. The states' behavioral changes depend on their decision process to minimize the multi-modal delivery costs. Also, it would model the U.S. port investment strategies which would affect the assumption of the 100-mile highway distance assumed in each destination states. As a major recipient port in the U.S., for example, Charleston may offer lower delivery costs to other destination cities than other adjacent states, possibly delivered via rail mode. These factors make the modeling task more complex and 
a new type of decision process approach would have to be combined with the current NIEMO approach.

Despite the limitations described above, this study accounted for various other transportation activity changes associated with importing and exporting weights, additionally to the change of transportation and warehousing activity values for foreign imports and exports. We expect to develop various smaller diversion scenarios; we only assumed a one-hundred percent diversion of foreign imports and exports arriving or leaving at the West Coast region, which is delivered to other states out of the region. Diverse diversion scenarios by scaling down will be more useful to figure out the future of the region with a minimal effort because NIEMO is linear. Furthermore, it will be useful to model local freight movements, for example, in Southern California by applying a local freight model developed by Giuliano et al. (2010).

For the next research progress to improve the limitations conducted in this study, we will consider the following points. First of all, various policy implications about recovery plans stemming from the possible losses of the West Coast ports should be addressed. Second, concerning the U.S. trade diversion derived by the canal expansion, we will develop an econometric model that captures several key relevant factors and measure the pure effect of Panama Canal expansion on the change of the U.S. trade. Finally, because the U.S. trade change at the West Coast seaports is also affected by demand side factors of foreign countries simultaneously with the canal expansion, an elaborated model that combines this empirical pattern change in demand with the current economic impact model needs to be developed.

\section{Acknowledgement}

We thank for valuable comments of two anonymous referees which improved the quality of this article. We sincerely appreciate Professors Harry W. Richardson and Peter Gordon for their intellectual support on U.S. port system and this study.

Authors' contributions

CP participated in the design of the study and performed the statistical analysis. Also, CP drafted the manuscript. JY conceived of the study and participated in its design, coordination, and editing the manuscript. Both authors read and approved the final manuscript.

\section{Competing interest}

We wish to thank the U.S. Department of Transportation (USDOT) through University Transportation Research Center, Region II, Research and Advanced Technology Initiative for sponsoring this research. This work could not have been possible without this support. However, any opinions, findings, conclusions, or recommendations in this article are those of the authors and do not necessarily reflect the view of USDOT.

Author details

${ }^{1}$ Future Strategy Research Division, International Logistics Research Department, Korea Maritime Institute, 26 Haeyang-ro 301 beon-gil Yeongdo-gu, Busan 49111, South Korea. ²Department of Urban and Regional Planning, University at Buffalo, 05L Hayes Annex C, Buffalo, NY 14214-3087, USA.

Received: 15 March 2016 Accepted: 12 July 2016

Published online: 04 August 2016

References

Ballou, R. H. (2004). Business Logistics/Supply Chain Management (5th ed.). Upper Saddle River, New Jersey: Pearson Education, Inc.

Bittner, J., Baird, T., Adams, T. Impacts of the Panama Canal Expansion on US Greenhouse Gas Emissions. Presented at 91st Annual Meeting of the Transportation Research Board, Washington, D.C., 2012.

Boske, L.B. \& Harrison, R. The Dynamics of U.S.-Asian-South American Waterborne Trade and the Panama Canal Expansion: Their Anticipated Impacts on Texas Ports and the State's Economy, Center for Transportation Research, The University of Texas at Austin, 2013

CanagaRetna, S.M. (2013). 2013 Update on the Panama Canal Expansion and Ports in the Atlantic and Gulf Coast states - An issue alert from the SLC. Southern Legislative Conference of the Council of State Governments. 
Cho, J., Gordon, P., Moore, J.E., II, Pan, Q., Park, J.Y., \& Richardson, H.W. (2015). TransNIEMO: economic impact analysis using a model of consistent interregional economic and highway network equilibria. Transportation Planning and Technology, 38(5), 483-502.

Corbett, J.J., Deans, E., Silberman, J., Morehouse, E., Craft, E., \& Norsworthy, M. (2012). Panama Canal expansion: emission changes from possible US west coast modal shift. Carbon Management, 3(6), 569-588.

Giuliano, G., Gordon, P., Pan, Q., Park, J.Y., \& Wang, L. (2010). Estimating freight flows for metropolitan area highway networks using secondary data sources. Networks and Spatial Economics, 10(1), 73-91.

Jones, I. (1996). Miami's makeover: the city has become a window to world commerce. World Trade, 9(11), 14-15.

Knight, K. The Implications of Panama Canal Expansion to U.S. Ports and Coastal Navigation Economic Analysis, Institute for Water Resources White Paper, U.S. Army Corps of Engineers, 2008.

Kotkin, J. (1996). Cities of hope: thanks to global trade urban America's potential is revealed. World Trade, 9(4), 24-30.

Park, J.Y. (2008). The economic impacts of dirty- bomb attacks on the Los Angeles and long beach ports: applying the supply-driven NIEMO (National Interstate Economic Model). Journal of Homeland Security and Emergency Management, 5(1), Article 21

Park, J.Y., \& Richardson, H.W. (2014). Refining the Isard Multiregional Input-output Model Theory. In P Nijkamp, A Rose, and K Kourtit (Eds.), Regional Science Matters: Studies Dedicated to Walter Isard (p. 35-54). Springer-Verlag.

Park, J.Y. The Supply-Driven Input-output Model: A Reinterpretation and Extension. Presented at 46th Annual Meeting of the Western Regional Science Association, Newport Beach, CA, USA, February 21 - 24, 2007.

Park, J.Y., Gordon, P., Kim, S.J., Kim, Y.K., Moore II, J.E., Richardson, H.W. (2008). Estimating the State-by-State Economic Impacts of Hurricane Katrina. In HW Richardson, P Gordon and JE Moore II (Eds.), Natural Disaster Analysis after Hurricane Katrina Cheltenham. Edward Elgar (p147-186).

Park, J.Y., Cho, J., Gordon, P., Moore, J.E., II, Richardson, H.W., \& Yoon, S. (2011). Adding a freight network to a national interstate input-output model: a TransNIEMO application for California. Journal of Transport Geography, 19(6), 1410-1422.

Richardson, H.W., Park, J.Y., Moore II, J.E., Pan, Q. National Economic Impact Analysis of Terrorist and Natural Disasters. Edward Elgar, 2014.

Rodrigue, J.P. (2010). Factors Impacting North American Freight Distribution in View of the Panama Canal Expansion. The Van Horne Institute.

Rondinelli, D.A., Johnson, J.H., Jr., \& Kasarda, J.D. (1998). The changing forces of urban economic development: globalization and city competitiveness in the 21 st century. Cityscape: A Journal of Policy Development and Research, 3(3), 71-105.

Urban, D.M. (2007). Neoclassical growth, manufacturing agglomeration, and terms of trade. Review of International Economics, 15(5), 1014-1035.

\section{Submit your manuscript to a SpringerOpen ${ }^{\circ}$ journal and benefit from:}

- Convenient online submission

- Rigorous peer review

- Immediate publication on acceptance

- Open access: articles freely available online

- High visibility within the field

- Retaining the copyright to your article 